\title{
SOME REMARKS ON THE BIRTH OF A FATHER DAVID'S DEER, ELAPHURUS DAVIDIANUS MILNE EDW.
}

\author{
by \\ C. VAN DOORN, \\ Stichting Koninklijke Rotterdamse Diergaarde \\ and \\ E. J. S LIJPER \\ Zoölogisch Laboratorium, Universiteit van Amsterdam
}

At the Royal Zoological Gardens "Blijdorp" at Rotterdam May 6th 1958 a Father David's Deer gave birth to a female calf. It was the first young of this three year old doe.

During the days before the day of birth the doe was seen several times leaping upon the buck. Experience with other Ungulates has taught that such behaviour may be regarded as an indication that the time of delivery is approaching. On the day of birth the doe refused her food as has been observed in many other mammals. She lay down very often, gnashed her molar teeth and made movements with her head towards the belly and the udder, the ears flattened to the neck, as if she was suffering from cramps. One had the impression, however, that the expulsion of the young was kept back until the keeper went home and the door of the stable was closed. Apparently a great number of mammals prefer to give birth to their young in the quietest part of the space of 24 hours. For most mammals this is the evening or the night, but bats very frequently give birth during the day which is their time of rest (Slijper, 1959). A postponement of birth until all is quiet has frequently been observed in zoological gardens. In natural surroundings the Ringed Seal (Phoca hispida Schreb.) and other Seals are said to be able to postpone birth as long as 10 days if the weather is very bad (KrumbiegeL, 1947).

The first signs of labour connected with the expulsion of the young were observed at 18.00. At 18.10 the amniotic bladder was already protruding distinctly. The amniotic fluid was transparent and the forelegs were clearly visible (Fig. 1). During the next 80 minutes the animal stood up and lay down alternatively, as has been observed in many other hoofed mammals. The amniotic bladder broke before 19.00 when the snout of the fawn was visible lying on the forelegs (Fig. 2). It meant that this was a birth in head-presentation as is normal with Ungulates (SLIJPER, 1959). From 19.00 onward the fawn was expelled gradually. During the later stages of this period the mother was lying down more and more. She made no sound with the exception of the gnashing of the molar teeth. At 19.42 about three quarters of the fawn were expelled (Fig. 3).

At 19.45 the doe rose suddenly, the fawn slipped out and the umbilical cord ruptured. This way of terminating birth appears to be usual with Ungulates (SLIJPER, 1959), although notably with Father David's Deer two cases have been reported in which the mother stood up during the final stage of the expulsion phase and the fawn fell on the ground (Communications of S. ANderson, København and E. C. Appleby, Edinburgh). With other Ungulates as well this way of terminating birth is very often seen and with some species (for example Giraffes and Lamas) it even seems to be the usual way.

The expulsion phase of the above described birth lasted for an hour and 45 minutes. This is in accordance with the average time observed in Ungulates and all other mammals that give birth to comparatively big and well developed young $(1 / 2-2$ hours with the exception of Equidae where the expulsion phase is shorter as a rule $(5-20 \mathrm{~min}$.); SLIJPER, 1959). In mammals with very small and not so well developed young the expulsion phase usually lasts about 15-20 minutes although it can be much shorter (1-3 min.). According to the opinion of Miss Grjzen (1958) the expulsion phase of Ungulates would be very much prolonged if the animals are observed by man or if they are disturbed in any other way, as is often the case in zoological gardens. The shortest duration of birth with Giraffes reported by Miss Gijzen, however, is 20 minutes, and several long drawn-out births have been reported from zoological gardens where there was no disturbance 
at all. On one of the very few occasions when a birth in natural surroundings could be observed (birth of an Indian Elephant; see NicHOLA, 1953 and Deraniyagala, 1955), it lasted for an hour and a half. Consequently it appears that in any case birth with animals who have big and well developed young lasts much longer than with animals who have young that are very small at birth.

The most remarkable facts observed at the birth of the Father David's Deer were the length of the umbilical cord and the place where it was ruptured. As can be seen from the table given by SLrJPER (1959), in all Ruminants the length of the umbilical cord varies between 20 and $45 \%$ of the length of the newborn. This is entirely in accordance with a case of a Father David's Deer described by HaMLToN and Harrison (1951) where the length of the cord amounted to $30 \%$ of the length of the newborn. Although in the present case no exact measurements of the cord could be made, its length was estimated to be approximately $70 \%$ of that of the fawn.

It is not quite clear whether the great length of the cord caused the other remarkable fact, viz. the place where it ruptured. This happened at a distance of approximately $50 \mathrm{~cm}$ from the umbilicus of the young, a very unusual place, because normally in
Ungulates the cord ruptures at a distance of about 1-3 cm from the belly of the newborn. Mr. E. H. Tong of Whipsnade Park, Dunstable, who has a large experience of births of Father David's Deer, kindly informed us that in all cases he observed the cord of these animals ruptured very close to the umbilicus. In Pinnipedia, Suidae and Hippopotamidae the cord may rupture at any place of its whole length, in Camels, Okapi's and Giraffes the distance from the umbilicus may vary between 10 and $40 \mathrm{~cm}$ (SLIJPER, 1959), but in all other Ruminants such a long distance is quite unusual.

Immediately after birth the doe licked the fawn until it was dry. She removed the remains of the foetal membranes and ate them. When licking the belly of the newborn the doe came upon the umbilical cord. She took it in her mouth and ground it between the molar teeth. Such behaviour has never been described in literature and was never observed by us in any Ungulate. It is quite normal in Carnivores, many Rodents and in Primates who eat the umbilical cord when they eat the afterbirth. The appearance of the afterbirth was not observed in the present case. It was not found next day so it had apparently been eaten by the doe.

\section{REFERENCES}

Deraniyagala, P. E. P., 1955: Some Extinct Elephants, their Relatives and the two Living Species. Ceylon $\mathrm{Na}$ tional Museum Publ. Colombo.

GiJzEN, A., 1958: Quelques observations concernant la naissance et la croissance des Girafes au jardin zoologique d'Anvers. Mammalia 22, p. 112.

Hammton, W. J. and R. J. Harrison, 1951: Placentation in Père David's Deer. Nature 167, p. 443.
Krumbieged, I., 1937: Notizen zur Biologie einiger Säugetiere von Spitzbergen und Grönland. Zool. Garten N.F. 9, p. 214.

NichоцА, C. W., 1953: Administration Report Department Wild Life Colombo, Ceylon.

Slujper, E. J., 1959: Die Geburt der Säugetiere. In: Handbuch der Zoologie (Kükenthal) Bd. 8, Berlin, de Gruyter. Will probably appear in 1959. 